\title{
Socio-demographic and medical factors associated with patients' satisfaction with nursing care and their perception of pain
}

\author{
Danuta Zarzycka, ${ }^{1, A, C-D, F}$, Elżbieta Bartońn ${ }^{2, B-C}$, Anna Mazur ${ }^{3, C, E}, K_{\text {Krzysztof Turowski }}^{4, E-F}$ \\ ${ }^{1}$ Department of Pediatric Nursing, Faculty of Health Sciences, Medical University of Lublin, Lublin, Poland \\ ${ }^{2}$ Department of Neurosurgery and Pediatric Neurosurgery, Medical University of Lublin, Lublin, Poland \\ ${ }^{3}$ Department of Neuro-Rehabilitation, Institute of Rural Health, Lublin, Poland \\ ${ }^{4}$ Department of Neurology, Faculty of Health Sciences, Medical University of Lublin, Lublin, Poland \\ A - Research concept and design, B - Collection and/or assembly of data, C - Data analysis and interpretation, \\ $D$ - Writing the article, E - Critical revision of the article, F - Final approval of article
}

Zarzycka D, Bartoń E, Mazur A, Turowski K. Socio-demographic and medical factors associated with patients' satisfaction with nursing care and their perception of pain. Ann Agric Environ Med. 2019; 26(2): 298-303. doi: 10.26444/aaem/90385

\section{Abstract}

Introduction and objective. Patient satisfaction with nursing care is one of important indicators of health care quality. As for pain, it is an indicator of patient health. The goal of the study is to identify socio-demographic and medical factors that differentiate the assessment of satisfaction with nursing care of hospitalized patients.

Materials and method. The study involved performing a diagnostic survey using standardized instruments, i.e. the Newcastle Satisfaction with Nursing Scale (NSNS) and the Visual Analog Scale by Barbara J. Headley for pain scoring. The study included 205 patients hospitalized for lumbar pain syndrome on two neurosurgery wards in Poland. The mean patient age was 51 years. Most respondents declared having high school or vocational education. The mean time of hospitalization before the study was 2 days.

Results. The results demonstrated that patient satisfaction with nursing care is independent of patient age, education, duration of hospitalization, or number of hospitalizations. In contrast, the experience of nursing care is dependent on education, and less educated patients (primary or vocational education) had higher scores in this category. With regards to pain, it was perceived as more intense by women and by patients hospitalized for a shorter period of time.

Conclusions. Satisfaction with nursing care among patients with lumbar pain syndrome does not depend on sociodemographic or medical variables. Experience of nursing care depends on patient's education.

\section{Key words}

patient satisfaction with nursing, socio-demographic factors, medical factors, pain

\section{INTRODUCTION}

Patient satisfaction is one of the fundamental factors in monitoring and ensuring the quality of health care $[1,2]$, and nursing care is the most important means of ensuring its high standard $[3,4,5]$.

As reported in multiple studies, patient satisfaction is a multi-faceted concept that is not easily defined in a precise manner $[2,6,7,8,9]$. The term "satisfaction" is derived from the Latin satis, meaning "enough" i.e. that which is required to fulfill an individual's needs, expectations or desires, so that there is no room for complaint $[10,11]$. In one of the first and still essential definitions, Risser emphasizes the fact that patient satisfaction with nursing is the degree of convergence between patient's expectation of ideal care and the perception of care actually received [12]. Patient satisfaction with care comprises a continuum, from complete dissatisfaction to complete satisfaction [2]. Singh and other authors suggest that the individual situation is the main source of variability in terms of "satisfaction", thus emphasizing the emotional aspect of satisfaction with care that exists beside the obvious cognitive assessment [13, 14, 15].

Address for correspondence: Danuta Zarzycka Department of Pediatric Nursing, Faculty of Nursing and Health Sciences, Medical University of Lublin, Poland e-mail: danuta.zarzycka@umlub.pl

Received: 24.02.2018; accepted: 24.04.2018; first published:06.06.2018
Merkouris et al. comment that patient expectations are shaped by patient characteristics, attitudes, and previous experiences of care [16]. Other factors include patient health [17] and the characteristics of the health care system [18].

A review of European and US studies enabled additional determination of the care environment and the number of nurses per patient, which significantly impact on patient satisfaction [19], as well as professional skills that ensure effective pain relief [4].

Similarly, satisfaction with the hospital experience is a complex and multi-faceted notion that comprises relationships with the medical staff, the physical environment, and/or the organization of health care [20].

The concept of patient satisfaction with care is inseparable from the concept of patient experience with nursing care. The satisfaction with care of a particular person is the result of what he or she experiences across several dimensions of using the health care system. A large part of the literature describing how patients perceive their experience in the field of healthcare focused on the satisfaction of patients. The concept of patient experience is surprisingly complex. According to Berkowitz (2016), the concept of patient satisfaction is connected with patient's direct and indirect experiences with the health care system and interaction with healthcare service providers, in particular with the communication process between them [21]. In contrast, Batbaatar et al. (2015) 
emphasize the deficiencies in the adaptation of marketing theories to research of patient experiences of care and satisfaction with the care [22]. However, patient satisfaction is the result of a comparison between the perception of received care and the expected care. Thus, patients evaluate both the health care services and the service providers from their own subjective point of view. Although patients may be unable to assess specific technical aspects of the services, they are the best source of accurate information on communicativeness, simplicity of explanations, and usefulness of information received during pain treatment in a hospital setting, as well as the only source on whether they were treated in a respectful and dignified manner $[23,24]$.

As emphasized multiple times, satisfaction with care is subjective, and affected by the patient's health or symptoms. The most common symptom, and a fundamental one in spinal pain syndromes, is pain, which is also subjective. Pain (Latin: dolor, Greek: algos, odyne) is a personal, subjective phenomenon involving a negative, distressing sensory and emotional experience produced in the conscious brain in response to a tissue damaging event (called a "noxious stimulus"), or in some cases, in the absence of such a stimulus.

The relationship between perceived pain and stimuli is variable and dependent on individual's preconceptions and expectations, as well as their cognitive and emotional state, rather than on the nature of the stimulus itself [25]. Therefore, pain is any experience named so by the patient, regardless of any associated objective symptoms. Pain is considered a trigger for various human behaviours, including the expression of judgment or opinion [26]. Pain is the most common health problem in Europe. In particular, chronic and recurring pain is considered a separate health problem, a disease in itself. Studies carried out in local communities showed that nearly $50 \%$ of adults interviewed had suffered from one or more types of pain or discomfort at some point in time [27]. Pain in the lumbar spine, which is most likely the first symptom of lumbar discopathy, is one of the most troublesome diseases preventing patients from performing professional, social, and family roles. Sixty to ninety percent of people suffer from lumbar spine pain which is a serious and widespread social problem. It is the most common reason for limiting professional activity for people before 45 years of age. It is the most common reason for absence or resignation from work, payment of sickness, rehabilitation and pension benefits. There can be acute and chronic pain lasting longer than three months, requiring an MRI scan and, most likely, surgical treatment [28-32].

\section{OBJECTIVE}

The aim of the study is to present the socio-demographic and medical factors that differentiate patient assessment of satisfaction with nursing care and perception of pain, which will facilitate improved controls and ensure the quality of care.

\section{MATERIALS AND METHOD}

The study was performed between January - October 2017, in two neurosurgery departments in Central and Eastern Poland. Patients were recruited in a targeted manner, based on criteria recommended by the authors of the tools used and specific to the project: minimum patient age 18 years, minimum duration of hospitalization -2 days, ability to read and write, unimpaired consciousness, basis for hospitalization - spinal pain syndrome, and voluntary informed consent to participate in the study.

The study was approved by the Medical University of Lublin Bioethics Committee (Approval No.: KE-0254/181/2016). The research project involved performing a diagnostic survey using questionnaires. Two standardized tools were used, as well as the authors' own survey questionnaire. Patient satisfaction with nursing care was assessed using the Newcastle Satisfaction with Nursing Scale (NSNS) developed by the Centre for Health Services Research at Newcastle University in England [33], adapted into Polish by GutyszWojnicka [34]. The scale is comprised of three sections: experiences of nursing care (26 items), satisfaction with nursing care (19 items), and respondent information ( 8 items).

With regard to internal consistency, the original NSNS had a Cronbach's alpha of 0.91 for the experience subscale, and 0.96 for the satisfaction subscale. In the Polish version, the Cronbach's alpha was 0.92 for the experience subscale, and 0.81 for the satisfaction subscale [34].

Pain was scored using Barbara Headley's Visual Analog Scale, which allows for evaluating the intensity of pain experienced by the patient in relation to performing daily activities (14 items) [35].

The authors' own survey questionnaire included basic information on the time and place of hospitalization, patient age, sex, and education (10 items).

Statistical analysis. Statistical analyses were performed using IBM SPSS 24 software. Population characteristics were based on the calculation of percentage distribution of qualitative variable prevalence, as well as the mean, standard deviation, and maximum and minimum values of quantitative parameters. Data distribution curves were estimated using the Shapiro-Wilk and Kolmogorov-Smirnov tests. As the distributions of the variables analyzed did not conform to Gaussian distribution, intra-group comparisons were performed using the non-parametric Kruskal-Wallis test, and test results were complemented with an effect size measure $\varepsilon^{2}$. The Mann-Whitney U-test was used to increase result accuracy, with Glass' rank coefficient used as an effect size measure. Before estimating multivariate models and correlations between parameters using interval scales, the data underwent standardization in order to ensure homogeneous data ranges. The co-occurrence of the study variables was estimated using Pearson's $r$ linear correlation coefficient, preceded by verification of linearity. Multivariate analyses were performed using UNIANOVA, a procedure included in the general linear model (GLN). The threshold for probability of erroneous rejection of the null hypothesis $\mathrm{H}_{0}$ which is in fact not false was set at 0.05 .

Study sample characteristics. The study group included 205 patients hospitalized in neurosurgery wards for spinal pain syndrome. $50.2 \%$ of the patients were female, $49.8 \%$ were male. The youngest patient was aged 18 and the oldest 76; mean age was over $50(\mathrm{M}=51.31 ; \mathrm{SD}=13.25)$. The largest percentage of patients declared they were high schooleducated $(\mathrm{N}=85 ; 41.5 \%)$. Nearly $30.0 \%$ of the patients had graduated from vocational schools $(\mathrm{N}=61 ; 29.8 \%)$. The 
percentage of patients with college or university education did not exceed $17.0 \%(\mathrm{~N}=34 ; 16.6 \%)$, and the smallest group were patients who had only graduated from primary school $(\mathrm{N}=25 ; 12.2 \%)$. Generally, patients had undergone between 1 and 23 hospitalizations, while the mean number of hospitalizations was $3.10(\mathrm{SD}=2.84)$. The patients remained hospitalized on the neurosurgery ward between 2 and 41 days, with the mean exceeding 5 days $(M=5.06 ; \mathrm{SD}=4.29)$.

To verify the hypothesis that patient satisfaction with nursing and their perceived pain differ based on sociodemographic characteristics (gender and education), twofactor UNIANOVA analysis of variance was performed in a $2 \times 4$ intergroup system. Independent variables included patient gender (female vs. male) and education (primary vs. vocational vs. high school vs. college/university). Dependent variables included satisfaction with nursing care and perceived pain. The results of comparisons between genders in terms of neurosurgical patient satisfaction with nursing and perceived pain are shown in Table 1.

Table 1. Comparison of neurosurgical patient satisfaction with nursing and perceived pain depending on patient gender

\begin{tabular}{lcccccccc}
\hline & \multicolumn{4}{c}{ Gender } & \multicolumn{3}{c}{ Group comparison } \\
\cline { 2 - 7 } Scale & \multicolumn{2}{c}{ Female } & \multicolumn{2}{c}{ Male } & $F$ & $p$ & $\eta^{2}$ \\
\cline { 2 - 7 } & $M$ & $S D$ & $M$ & $S D$ & & & \\
\hline Experiences of nursing care & 5.71 & 0.58 & 5.62 & 0.55 & 1.08 & 0.300 & - \\
\hline $\begin{array}{l}\text { Satisfaction with nursing } \\
\text { care }\end{array}$ & 3.02 & 0.55 & 3.00 & 0.40 & 0.03 & 0.868 & - \\
\hline Pain score & 89.14 & 21.51 & 81.15 & 21.77 & 5.50 & 0.020 & 0.027 \\
\hline Source: own research & & & & & & &
\end{tabular}

Analyses showed a statistically significant main effect of the gender variable on perceived pain, $F(2.205)=5.50$; $p=0.020 ; \eta^{2}=0.027$, which indicates that women $(M=89.14$; $S D=21.51)$ experience a stronger impact of pain on their daily activities than men $(M=81.15 ; S D=21.77)$.

The effect size for pain score and gender was small, which indicates a weak correlation between the two dimensions. The data obtained indicate no statistically significant main effect of the gender variable on the experience of the nursing care received, $F(2.205)=1.08 ; p$ n.s., or satisfaction with the nursing care received, $F(2.205)=0.03 ; p$ n.s.

Comparison of satisfaction with nursing and perceived pain in terms of patient education is shown in Table 2.

The calculations performed showed a statistically significant main effect of the education variable on experiences of nursing care, $F(3.205)=7.17 ; p<0.001 ; \eta^{2}=0.100$. The effect size for experiences of nursing care and patient education was moderate, which indicates a moderately strong correlation between the dimensions.

Neurosurgical patients diagnosed with lumbar pain syndrome who had had primary education $(M=5.93 ; S D=0.45)$ had a better experience of nursing care received at the hospital than those with high school $(M=5.66 ; S D=0.48)$ or college/ university education $(M=5.32 ; S D=0.55)$, but did not differ in this respect from those who declared having had vocational education $(M=5.78 ; S D=0.63)$. Patients with vocational education $(M=5.78 ; S D=0.63)$ had a better experience of the nursing care received than those with college/university education $(M=5.32 ; S D=0.55)$, but did not differ from those with high school education $(M=5.66 ; S D=0.48)$. Patients with high school education $(M=5.66 ; S D=0.48)$ were found to have a better experience of nursing care received than those with college/university education $(M=5.32 ; S D=0.55)$. Statistical analyses did not demonstrate any statistically significant main effect of the education variable on satisfaction with the nursing care received, $F(3.205)=2.03 ; p$ n.s., or perceived pain, $F(3.205)=0.08$; $p$ n.s.

The study also involved estimating the effect of interaction between both factors (gender and education) on the one hand, and satisfaction with care or perceived pain on the other, in the neurosurgical patients studied. The data obtained in the study are shown in Table 3.

These analyses showed no statistically significant effect of the sex and education variables on the experience of nursing care, $F(3.205)=2.00$; $p$ n.s., satisfaction with nursing care, $F(3.205)=0.56$; $p$ n.s., or perceived pain, $F(3.205)=0.75 ; p$ n.s. This indicates that the groups under analysis provided similar scores for their experience of and satisfaction with the nursing care received at the neurosurgery ward, as well as for their perceived pain.

The next stage of the study verified whether patient age, age at completion of education, duration of hospitalization, and the number of previous hospitalizations coincide with experiences of nursing, satisfaction with nursing, and perceived pain. The calculation results are shown in Table 4.

These correlation analyses demonstrate a weak inverse correlation between age at completion of education and experiences of nursing care, $r=-0.19 ; p=0.006$, which indicates that the earlier a patient had finished their education, the more positive their experience of nursing care received at the neurosurgery ward. There was also a weak negative correlation between the duration of hospitalization and the perceived functional consequences of pain, $r=-0.21 ; p=0.003$. The data suggest that the longer a patient is hospitalized, the weaker the negative perception of the experienced pain.

Table 2. Comparison of neurosurgical patient satisfaction with nursing and perceived pain depending on patient education

\begin{tabular}{|c|c|c|c|c|c|c|c|c|c|c|c|}
\hline \multirow{3}{*}{ Scale } & \multicolumn{8}{|c|}{ Education } & \multicolumn{3}{|c|}{ General comparisons } \\
\hline & \multicolumn{2}{|c|}{ primary $(\mathrm{P})$} & \multicolumn{2}{|c|}{ vocational (V) } & \multicolumn{2}{|c|}{ high school (H) } & \multicolumn{2}{|c|}{ college/university (U) } & \multirow{2}{*}{$F$} & \multirow{2}{*}{$p$} & \multirow{2}{*}{$\eta^{2}$} \\
\hline & $M$ & $S D$ & $M$ & $S D$ & $M$ & $S D$ & $M$ & $S D$ & & & \\
\hline Experiences of nursing care & 5.93 & 0.45 & 5.78 & 0.63 & 5.66 & 0.48 & 5.32 & 0.55 & 7.17 & 0.001 & 0.100 \\
\hline Satisfaction with nursing care & 2.96 & 0.49 & 3.04 & 0.43 & 3.13 & 0.49 & 2.92 & 0.51 & 2.03 & 1.111 & - \\
\hline Pain score & 89.33 & 13.98 & 86.18 & 25.38 & 90.31 & 21.93 & 90.94 & 18.65 & 0.08 & 0.970 & - \\
\hline & \multicolumn{2}{|c|}{$P-V$} & \multicolumn{2}{|l|}{$\mathrm{P}-\mathrm{H}$} & $\mathrm{P}-\mathrm{U}$ & \multicolumn{2}{|r|}{$\mathrm{V}-\mathrm{H}$} & \multicolumn{2}{|c|}{$\mathrm{V}-\mathrm{U}$} & \multicolumn{2}{|c|}{$\mathrm{H}-\mathrm{U}$} \\
\hline Experiences of nursing care & \multicolumn{2}{|c|}{0.135} & \multicolumn{2}{|l|}{0.030} & 0.001 & \multicolumn{2}{|r|}{0.404} & \multicolumn{2}{|c|}{0.001} & \multicolumn{2}{|c|}{0.002} \\
\hline
\end{tabular}


Table 3. Comparison of neurosurgical patient satisfaction with nursing and perceived pain depending on patient gender and education

\begin{tabular}{|c|c|c|c|c|c|c|c|c|c|c|c|c|}
\hline \multirow{3}{*}{ Scale } & \multirow{3}{*}{ Sex } & \multicolumn{8}{|c|}{ Education } & \multicolumn{3}{|c|}{ Group comparison } \\
\hline & & \multicolumn{2}{|c|}{ primary $(\mathrm{P})$} & \multicolumn{2}{|c|}{ vocational (V) } & \multicolumn{2}{|c|}{ high school $(\mathrm{H})$} & \multicolumn{2}{|c|}{ college/university (U) } & \multirow{2}{*}{$F$} & \multirow{2}{*}{$p$} & \multirow{2}{*}{$\eta^{2}$} \\
\hline & & $M$ & $S D$ & $M$ & $S D$ & $M$ & $S D$ & $M$ & $S D$ & & & \\
\hline \multirow{2}{*}{$\begin{array}{l}\text { Experiences of } \\
\text { nursing care }\end{array}$} & Female & 6.11 & 0.38 & 5.71 & 0.66 & 5.58 & 0.53 & 5.41 & 0.53 & \multirow{2}{*}{2.00} & \multirow{2}{*}{0.151} & \multirow{2}{*}{-} \\
\hline & Male & 5.74 & 0.44 & 5.76 & 0.61 & 5.74 & 0.42 & 5.22 & 0.57 & & & \\
\hline $\begin{array}{l}\text { Satisfaction with } \\
\text { nursing care }\end{array}$ & Female & 3.00 & 0.52 & 3.10 & 0.48 & 3.09 & 0.58 & 2.90 & 0.60 & 0.56 & 0.645 & - \\
\hline \multirow{2}{*}{ Pain score } & Female & 89.33 & 13.98 & 86.18 & 25.38 & 90.32 & 21.93 & 90.94 & 18.65 & \multirow{2}{*}{0.75} & \multirow{2}{*}{0.524} & \multirow{2}{*}{-} \\
\hline & Male & 79.92 & 17.81 & 84.97 & 23.11 & 78.29 & 22.24 & 81.56 & 21.39 & & & \\
\hline
\end{tabular}

Source: own research.

Table 4. Co-occurrence of socio-demographic and medical variables with satisfaction with care and perceived pain in the studied neurosurgical patient sample

\begin{tabular}{lccc}
\hline Variables & $\begin{array}{c}\text { Experiences of } \\
\text { nursing care }\end{array}$ & $\begin{array}{c}\text { Satisfaction with } \\
\text { nursing care }\end{array}$ & Pain score \\
\hline Age & 0.04 & -0.01 & -0.09 \\
\hline Age at the end of education & $-0.19^{* *}$ & -0.05 & -0.06 \\
\hline Duration of hospitalization & 0.09 & 0.08 & $-0.21^{*}$ \\
\hline Number of hospitalizations & 0.01 & -0.05 & 0.13 \\
\hline
\end{tabular}

* correlation significant at $0.003 ;{ }^{* *}$ correlation significant at 0.006 . Source: own research.

These results show no statistically significant associations between any other dimensions, $p$ n.s.

\section{DISCUSSION}

Based on the presented findings, the authors conclude that patient satisfaction with nursing care does not depend on patient age, education, duration of hospitalization, or the number of hospitalizations. Experiences of nursing care did depend, however, on education, and less educated patients (primary or vocational education) had higher scores in this category. Pain was perceived as more intense by women and by patients hospitalized for a shorter time.

These findings can be compared with the literature on the subject, taking into consideration the specific cultural characteristics of the patients studied. Among Polish studies, findings from the first application of the NSNS in a study on satisfaction with nursing care by Gutysz-Wojnicka are noteworthy. In total, the study included 787 patients from 9 departments in 6 Polish hospitals. No association was found in the study between patient education and experiences of or satisfaction with nursing care. Patient age significantly affected experiences of nursing care $(\mathrm{p}=0.0005)$ and satisfaction with care $(\mathrm{p} \leq 0.05)$. Nursing care scoring differed between male and female patients. Men obtained higher scores, both in the experience and in the satisfaction scales. The lowest scores for experiences of nursing care were given by patients hospitalized for more than 30 days. In terms of satisfaction with care, there were no differences between patients with different durations of hospitalization $[11,33]$. Wierzbicka and Jankowska-Polańska, who studied a sample of 100 patients of internal medicine wards, demonstrated correlations for socio-demographic factors, such as patient age (weak correlation), education (moderately strong correlation with experiences, weak correlation with satisfaction), and gender (moderate correlation with experiences, weak correlation with satisfaction) [36]. Other studies indicate no major differences in terms of experiences of and satisfaction with care among patients undergoing surgical treatment for cervical or lumbar discopathy, finding very high scores ranging from $74 \%-82 \%$ in this group [37], and high scores in another group of surgical patients [38], or in non-surgical patients [39]. Patient satisfaction with nursing care in post-operative pain tends to be moderate, with an overall score of 60.84 [40]. In summary, patients in Polish hospitals have a high level of satisfaction and positive experiences of nursing care, although the socio-cultural determinants of these values are rather diverse, as is the very understanding of satisfaction with care [41].

In Europe, the first study using NSNS was performed by the authors of the scale, who surveyed 2078 patients from 20 hospital wards in north-east England, and found high satisfaction and experience scores, with score variability associated with patient age and education [33]. In a Norwegian study, the most significant predictors of overall patient satisfaction with hospital care were experiences reported by the patients, and fulfillment of expectations, while age was not a significant indicator of overall patient satisfaction [3]. The authors of a Turkish study reported high satisfaction and experience scores. Patients having undergone surgery, male patients, patients aged $40-59$, patients with a low educational level or low income, and patients hospitalized for a longer time, were the most satisfied with the care they received [20]. In a Brazilian study, greater satisfaction with nursing care was associated with lower patient education levels, patient perception of conditions of the ward, a kind and hospitable approach, sufficiently long treatment time, and instructions that met patient needs [42]. In Jordan, Alhusban et al. demonstrated a moderate level of patient satisfaction, but positive experiences of nursing care. Female patients were more satisfied with care than male patients, and patients in semi-private hospitals were more satisfied with care than those hospitalized in public hospitals [43]. The authors of a study on patient satisfaction with nursing in the US which included 43,838 patients reported that for female patients, the relationship with nurses was more important for overall satisfaction, and nursing care had the biggest impact on patient satisfaction [44]. In another study conducted by the same team, the top patient priorities which influenced satisfaction with care were health outcomes, respectful treatment by nurses and physicians, and conditions of hospitalization $[45,46]$. The conditions in the hospital and a higher number of nursing staff are primary determinants of satisfaction with care in Europe and the US [19]. 
Limitations. The results of the research included in the presented study article constitute an introductory part of a wider research project focused on studying patient satisfaction with nursing care provided in neurosurgical departments. The patients of the neurological department formed the control group. The study of hospitalized patient satisfaction with nursing care in neurosurgical wards is a difficult subject rarely undertaken by researchers. Determining the criteria of patient selection for research is an important challenge: patients with no obstacles of ethical and medical nature, and at the same time fully cognitive and communicative. Another limitation at this stage of research is the availability of patients marked by the number of specialist departments in which this project could be implemented.

\section{CONCLUSIONS}

The findings from studies on patient satisfaction with nursing care discussed above are rather diverse in terms of specific results, sample size, and the culture of the population in which each study was performed. The presented study contributes to this diversity, which should be an inspiration for efforts to generalize conclusions from this research, particularly with regard to areas that patients are dissatisfied with, as this is the only way to quickly improve the quality of care.

1. Experiences of and satisfaction with nursing care among neurosurgical patients with lumbar pain syndrome are independent of patient gender.

2. Regardless of their education, the studied patients had similar levels of satisfaction with the nursing care they received, as well as similar perceptions of the functional consequences of pain.

3. Neurosurgical patients diagnosed with lumbar pain syndrome who had completed primary education had a more positive experience of hospital nursing than those with high school or college/university education, but did not differ in this respect from those who declared completing vocational education.

4. Women and patients hospitalized for a shorter time reported more intense pain.

\section{REFERENCES}

1. Creanga AA, Gullo S, Kuhlmann AKS, Msiska TW, Galavotti C. Is quality of care a key predictor of perinatal health care utilization and patient satisfaction in Malawi? BMC Pregnancy Childbirth. 2017; 17(150). http://doi.org/10.1186/s12884-017-1331-7.

2. Maconko M, Kopański Z, Strychar J, Małek Ł. Patient satisfaction and the methods of its assessment. J Clin Healthcare 2016; 3: 14-19.

3. Bjertnaes OA, Sjetne IS, Iversen HH. Overall patient satisfaction with hospitals: effects of patient-reported experiences and fulfilment of expectations. BMJ Qual Saf. 2012; 21(1): 39-46, doi: 10.1136/ bmjqs-2011-000137.

4. Wagner D, Bear M. Patient satisfaction with nursing care: a concept analysis within a nursing framework. J Adv Nur. 2009; 65(3): 692-701.

5. Otani K, Kurz RS. The impact of nursing care and other healthcare attributes on hospitalized patient satisfaction and behavioral intentions. J Health Manag. 2004; 46(3): 181-196.

6. Piotrowska M, Kopański Z, Wróblewska M, Błaszczak B. Quality of life of persons with periodontal diseases. JPHNMR 2015; (1): 45-50.

7. Zyznawska J, Mańko G, Kulesa-Mrowiecka M, Brzostek M, Stach B. Wpływ rehabilitacji i programów profilaktycznych na jakość życia i próg odczuwalności bólu u pacjentów z dolegliwościami bólowymi dolnego odcinka kręgosłupa. JPHNMR 2013; 2: 30-41.
8. Lynn M, McMillen B, Sidani S. Understanding and measuring patients' assessment of the quality of nursing. care. Nurs Res. 2007; 56(3): 159166

9. Turris SA. Unpacking the concept of patient satisfaction: a feminist analysis. J Adv Nurs. 2005; 50(3): 293-298. doi:10.1111/j.13652648.2005.03392.x.

10. Plentara R, Knyszyńska A, Bażydło M, Zabielska P, Klim A, Kotwas A, et al. Patient satisfaction measure of the quality of primary health care. Pom J Life Sci. 2015; 61(3): 335-340.

11. Gutysz-Wojnicka A, Dyk D. Adaptacja polskiej wersji the Newcastle satisfaction with nursing scale (NSNS). Probl Pielęg. 2007; 15(3): $133-138$.

12. Risser N. Development of an instrument to measure patient satisfaction with nurses and nursing care in primary care settings. Nurs Res. 1975; 24: 45-52.

13. Singh J. The Satisfaction concept: a review and reconceptualization. Adv Consum Res. 1989; 16: 176-179.

14. Goktas SB, Yildiz T, Nargiz SK. The evaluation of nursing care satisfaction and patient learning needs in day case surgery. Indian J Surg. 2015; 77(3): 1172-1179. http://doi.org/10.1007/s12262-015-1234-7.

15. Hudak PL, Hogg-Johnson S, Bombardier C, McKeever PD, Wright JG. Testing a new theory of patient satisfaction with treatment outcome. Med Care. 2004; 42(8): 726-739. http://www.jstor.org/stable/4640811.

16. Merkouris A, Ifantopoulos J, Lanara V, Lemonidou C. Patient satisfaction: a key concept for evaluating and improving nurses services. J Nurs Manag. 1999; 7(1): 19-28. doi: 10.1046/j.1365-2834.1999.00101.x.

17. Dorigan GE, Guirardello EB. Patient satisfaction in a gastroenterology unit. Acta Paul Enferm. 2010; 23(4): 500-505. doi: 10.1590/S010321002010000400009.

18. Johansson P, Oleni M, Fridlund B. Patient satisfaction with care in the context of health care: a literature study. Scand J Caring Sci. 2002; 16(4): 337-344. doi: 10.1046/j.1471-6712.2002.00094.x.

19. Aiken LH, Sermeus W, Van den Heede K, Sloane DM, Busse R, McKee $\mathrm{M}$, et al. Patient safety, satisfaction, and quality of hospital care: cross sectional surveys of nurses and patients in 12 countries in Europe and the United States. BMJ 2012; 344: e1717.

20. Findik YU, Unsar S, Sut N. Patient satisfaction with nursing care and its relationship with patient characteristics. Nurs Health Sci. 2004; 12(2): 162-169. doi: 10.1111/j.1442-2018.2009.00511.x.

21. Berkowitz B. (January 31, 2016) "The Patient Experience and Patient Satisfaction: Measurement of a Complex Dynamic" OJIN: The Online Journal of Issues in Nursing Vol. 21, No. 1, Manuscript 1. DOI: 10.3912/ OJIN.Vol21No01Man01

22. Batbaatar E, Dorjdagva J, Luvsannyam A, Conceptualisation of patient satisfaction: a systematic narrative literature review. Perspect Public Health 2015; 135(5): 243-250 https://doi.org/10.1177/1757913915594196.

23. Cleary PD. A hospitalization from hell: a patient's perspective on quality. Ann Intern Med. 2003; 138(1): 33-9.

24. Leino-Kilpi H, Vuorenheimo J. Patient satisfaction as an indicator of the quality of nursing care. Vard Nord Utveckl Forsk. 1992; 12(3/4): 22-28.

25. The International Association for the Study of Pain (IASP) Committee on Taxonomy, Update May 22 2012). https://www.iasp-pain.org/ Taxonomy?navitemNumber=576\#Pain (access: 2018.01.14).

26. Turkiewicz-Maligranda A. Psychosocjologiczne uwarunkowania przeciwdziałania niepełnosprawności chorych w wieku produkcyjnym wynikającej z choroby dyskowej odcinka krzyżowo-lędźwiowego kręgosłupa - przegląd literatury. Piel Zdr Publ. 2013; 3(4): 353-357.

27. Deklaracja Europejskiej Federacji Oddziałów IASP (EFIC) odnośnie bólu przewlekłego jako głównego problemu zdrowotnego, traktowanego jako „choroba sama w sobie” https://ptbb.pl/bol/115-deklaracja-eficw-sprawie-bolu (access: 2018.01.14).

28. Bogduk N. On the definitions and physiology of low back pain, reffered pain and radicular pain. Pain. 2009; 147(1-3): 17-9. doi: 10.1016/j. pain.2009.08.020.

29. Morton M. Spine pain syndromes. Doctor's Guide. Przew Lek. 200; 5(11): 45-55.

30. Raczkiewicz D, Owoc A, Sarecka-Hujar B, Saran T, Bojar I. Impact of spinal pain on daily living activities in postmenopausal women working in agriculture. Ann Agric Environ Med. 2017; 24(1): 134-140. doi: https://doi.org/10.5604/12321966.1233996

31. Świerkot J.Back pain - etiology, diagnostics and treatment. Doctor's Guide. Przew Lek. 2006; 2(9): 86-98.

32. Baldwin NG. Lumbar disc disease: the natural history. Neurosurg. Focus 2002; 13(2): 1-4. doi/10.3171/foc.2002.13.2.3.

33. Thomas LH, McColl E, Priest J, Bond S, Boys RJ. Newcastle satisfaction with nursing scales: an instrument for quality assessments of nursing care. J Healthc Qual. 1996; 5(2): 67-72. 
34. Dyk D, Gutysz-Wojnicka A, Cudak EK, Talarska D. Cultural adaptation and psychometric evaluation of the Polish version of the Newcastle Satisfaction with Nursing Scale. Arch Med Sci. 2014; 10(4): 782-790. http://doi.org/10.5114/aoms.2014.44870.

35. Headley BJ, Chronic pain management. In: O’Sullivan SB, Schmitz TJ, editors. Physical rehabilitation: assessment and treatment, Philadelphia, David Company; 2006: 925-960.

36. Wierzbicka KB, Jankowska-Polańska B. Poziom jakości opieki pielęgniarskiej na przykładzie Uniwersyteckiego Szpitala Klinicznego we Wrocławiu. Współcz Piel Ochr Zdr. 2014; 3(4): 90-96.

37. Garczyk D. Zadowolenie chorego jako wyraz jakości opieki pielęgniarskiej u pacjentów leczonych chirurgicznie z powodu dyskopatii w odcinku szyjnym lub lędźwiowym kręgosłupa. Pielęg Neurol Neurochir. 2013; 2(2): 48-56.

38. Sierpińska L, Dzirba A. Poziom satysfakcji pacjenta z opieki pielęgniarskiej na oddziałach zabiegowych. Pielęg Chir Angiol. 2011; 1: 18-22.

39. Kozimala M, Putowski L. Ocena satysfakcji pacjentów z opieki pielęgniarskiej w Centrum Opieki Medycznej w Jarosławiu. Ann Acad Med Siles. 2009; 63(1): 20-27.

40. Bączyk G, Ochmańska M, Stępień S. Subiektywna ocena jakości opieki pielęgniarskiej w zakresie bólu pooperacyjnego u chorych leczonych chirurgicznie. Probl Pielęg. 2009; 17(3): 173-177.
41. Marcinowicz L, Chlabicz S, Grebowski R. Understanding patient satisfaction with family doctor care. J Eval Clin Pract. 2010, 16(4): 712-715. doi:10.1111/j.1365-2753.2009.01180.x.

42. Aldosari MA, Tavares MA, Matta-Machado ATG, Abreu MHG. Factors associated with patients' satisfaction in Brazilian dental primary health care. PLoS ONE. 2017; 12(11): e0187993. http://doi.org/10.1371/journal. pone.0187993 (access: 2018.01.14).

43. Alhusban MA, Abualrub RF. Patient satisfaction with nursing care in Jordan. J Nurs Manag. 2009; 17(6): 749-758. doi:10.1111/j.13652834.2008.00927.x.

44. Otani K, Buchanan PR, Desai SP, Herrmann PA. Different combining process between male and female patients to reach their overall satisfaction. J Patient Exp. 2016; 3(4): 145-150. http://doi. org/10.1177/2374373516685953.

45. Otani K, Herrmann PA, Kurz RS. Improving patient satisfaction in hospital care settings. Health Serv Manage Res. 2011; 24(4): 163-169.

46. Otani K, Waterman B, Dunagan WC. Patient satisfaction: how patient health conditions influence their satisfaction. J Healthc Manag. 2012; 57(4): 276-292; discussion 292-3. 